\title{
Procedural Justice and Affective Commitment: An Organizational Trust Mechanism
}

\author{
Aldi Kusnandar ${ }^{a, *}$ Sri Wahyuni ${ }^{b, *}$ \\ ${ }^{a}$ Magister of Management, Postgraduate Program, Universitas Lancang Kuning, Indonesia. \\ ${ }^{\mathrm{b}}$ Accounting, Fresgraduate Program, Sekolah Tinggi llmu Ekonomi Persada Bunda, Indonesia.
}

\begin{abstract}
The purpose of this study was to determine the effect of procedural justice on performance with organizational trust as a mediating variable. The population is the State Civil Apparatus of Indragiri Hilir Regency with a sample of 140 people. Data collection techniques using questionnaires and distribution using google form. Technical analysis of the data in this study is Structural Equation Modeling (SEM) using WarpPLS 7.0 for data processing. The result of this study is that procedural justice has an effect on the affective commitment of ASN to the Indragiri Hilir Regency Government. Procedural justice affects the trust of ASN organizations in the Indragiri Hilir Regency Government. Organizational trust affects the affective commitment of ASN to the Indragiri Hilir Regency Government. Procedural justice affects the affective commitment of ASN to the Indragiri Hilir District Government through organizational trust.
\end{abstract} \author{
ARTICLE HISTORY \\ Accepted: December 31, 2021 \\ KEYWORDS \\ Procedural Justice, \\ Affective Commitment
}

\section{Introduction}

Over the past few years, organizational justice and organizational trust have attracted the attention of scientists and practitioners of organizational studies (Tlaiss and Elamin, 2015), especially with regard to their impact on organizational effectiveness and the desire of employees to be cooperative and productive in organizations. (Aryee et al, in Rahmat et al., 2017). Organizational justice perceived by employees is the cause of the high level of employee organizational commitment. Procedural justice is a form of organizational justice that focuses on fairness in making decisions (Hwei and Santosa, 2012). Distrust in management was found to be a major constraint in relationships within the organization (McCune in Rahmat et al., 2017). In other words, employees who do not trust the organization and management are likely to have low commitment and ineffective work results (Tlaiss and Elamin, in Rahmat et al., 2017) According to McShane and Mary (2005) in Putri and Kusumaputri, (2014) In other words, employees who do not trust the organization and management are likely to have low commitment and ineffective work results (Allen and meyer, 1990 in Sihana, 2016). Because affective commitment is based on a psychological and emotional approach that is more precisely related to organizational justice (Sihana, 2016). Liu and Ding (2012); Gupta and Singh (2013); (Tlaiss and Elamin in Rahmat et al., 2017) revealing the impact of

\section{*CORRESPONDING AUTHOR.Email: safawahyuni@gmail.com.}


organizational justice on organizational trust from Indonesia is still rarely found in scientific publications.

In an organization, employees who do not have an attitude of trust in the organization and management are likely to have low commitment and ineffective work results (Tlaiss and Elamin, in Rahmat and Abdillah (2017). Widiastuti and Aisyah (2016) stated that procedural fairness is the perception that employees have when they see the company in carrying out the existing rules. The perceived fair or unfair regarding the processes and procedures that have been applied indicates a high or low level of procedural fairness according to subordinates. Thus, if the rules are implemented properly by the company, employees feel they are treated fairly and vice versa.

Research on affective commitment has been done by many previous researchers. Based on the results of previous research, it can be conveyed that procedural justice variables that can affect affective commitment such as research conducted by Sihana (2016); Hasmarini and Yuniawan (2008) and Irawan et al. (2016). There is a research gap from the results of research conducted by pareke (2003) in Irawan et al.(2016) which states that affective commitment is not influenced by procedural justice and the same thing is also found by Yuniawan (2008). In addition to procedural justice variables, affective commitment is also influenced by organizational trust expressed by research conducted by Putri and Kusumaputri (2014), Bloemer et al.(2013). Hayunintyas et al. (2018) in his research also found that organizational trust has an effect on affective organizational commitment.

Robbins (2008) in Putri and Kusumaputri (2014) which says that affective commitment can arise as a result of a need. This commitment is formed because the organization can make the management have a strong belief to follow all organizational values, strive to realize the organization's goals as the first priority, and the management's willingness to maintain its membership. The strong belief that is formed in regional organizations is that there is trust between fellow administrators, so that they feel like they are one family in the organization. Research conducted by Rahmat and Abdillah (2017) which says that affective commitment can arise as a result of a need. This commitment is formed because the organization can make the management have a strong belief to follow all organizational values, strive to realize the organization's goals as the first priority, and the management's willingness to maintain its membership.

The strong belief that is formed in regional organizations is that there is trust between fellow administrators, so that they feel like they are one family in the organization. Research conducted by Hayunintyas et al. (2018); Yulianti (2016); Oliver E. Ngodo (2008); Dolan (2014) and Demir (2011). In research conducted by Yulianti (2016) organizational trust mediates the relationship between procedural fairness and employee engagement. In research conducted by Hayunintyas et al.(2018) organizational trust mediates the relationship between organizational justice and organizational commitment, where in organizational justice one of the indicators is procedural justice. The role of organizational trust as a mediating variable was also found in the research Ahmad et al. (2020). 


\section{Theoretical support}

\section{Social Exchange Theory (SET)}

In this research, the underlying theory is the social exchange theory presented by Blau in 1986. The social exchange discussed is a theory that explains how individual employees complement each other. Exchange relationships with other people will produce a reward for us. Social exchange theory sees behavior and the environment as having a mutually influencing relationship. This exchange theory itself is more ecological in nature where there is an environmental influence on the behavior of actors and the influence of actors on their environment (Mighfar, 2015). This theory is the root of the exchange theory called behaviorism, where this relationship is the basis of the operant condition (Ritzer, George and Douglas, 2004) in (Mighfar, 2015). The Social Exchange point of view argues that people calculate the overall value of a relationship by subtracting the sacrifices from the rewards received (Mighfar, 2015).

For Homans, the basic principle of social exchange is "distributive justice" the rule that says that a reward must be worth the investment. The famous proposition related to this principle reads "a person in an exchange relationship with another person will expect the rewards received by each party to be proportional to the sacrifices that have been made - the higher the sacrifice, the higher the reward - and the profits received by each party must be proportional to the investment. - the higher the investment, the higher the profit" (Mighfar, 2015).

Assumptions made by social exchange theory regarding the nature of relationships:

a. Relationships are interdependent. In a relationship when a participant takes an action, both the individual participant and their relationship as a whole will be affected.

b. Relationship life is a process. The importance of time and change in the life of a relationship. In particular, time affects exchanges because past experiences guide judgments about rewards and sacrifices, and these judgments influence subsequent exchanges.

This theory can be used to examine the phenomenon of a person's social relationship or group moving or changing friends or group affiliations. Stayed in a group then out and in. By using these basic concepts as independent variables and the act of moving or changing as the dependent variable (Hamidi, 2007 in Mighfar, 2015)

\section{Procedural Fairness}

According to Simpson and Kaminski (2007) in Hwei and Santosa (2012) Procedural justice refers to the formal level of the decision-making process related to outcomes, including the determination of some employee complaint system or application regarding consequences at an early stage of decision-making (Simpson and Kaminski, 2007 in Hwei and Santosa, 2012). Procedural justice is the result of agreement through certain procedures and has the main target of regulations, laws, laws. This procedure cannot be separated from efforts to legitimize the action. If there is distributive justice that can be applied properly, then in a social 
environment or fair procedural justice organization will be able to avoid arbitrary abuse of power or control (Haryatmoko, 2002 in Hwei and Santosa, 2012).

Widiastuti and Aisyah, (2016) Procedural justice is the result of agreement through certain procedures and has the main target of regulations, laws, laws. This procedure cannot be separated from efforts to legitimize the action. If there is distributive justice that can be applied properly, then in a social environment or fair procedural justice organization will be able to avoid arbitrary abuse of power or control.

Baharuddin (2010) states that procedural justice is related to subordinates' perceptions of a form of fairness from all processes that have been implemented by superiors in the company and used to evaluate the performance of their employees. The perception of fair or unfair regarding the processes and procedures that have been applied indicates a high/low level of procedural justice according to subordinates. James L. Gibson (2012) defines procedural justice which refers to the fairness of organizational processes and procedures used to determine resources and allocation of decisions. According to Al-Zu'bi (2010) Procedural fairness refers to employees' perceptions of the fairness of the rules and procedures that govern a process. Accordinig to Robbins, (2012) defines procedural justice as follows "Procedural fairness is the perceived fairness of the process used to determine the distribution of rewards."

\section{Organizational Trust}

Trust defined by Mayer, Davis, and Schoorman (1995) in Demir (2011) as the willingness of a party to be vulnerable to the actions of another party based on the expectation that the other party will perform certain actions that are important to the trustee, regardless of the ability to monitor or control the other party'. In this context, trust is a key variable that predicts the behavior of individuals in an organization. Organizational trust attitudes with employees' expectations are important for caring for them and being responsive to their needs, now and in the future (Olson et al., 2006 in Demir, 2011) and to improve the quality of work life for both individuals and organizations.

In a study conducted by Oktug (2012), it was explained that companies that have a high level of trust between members in a company tend to have loyal employees and have a comparable level of job satisfaction. In addition, it is explained that organizational trust in a company also has a positive relationship with the development process of a company. This explains that the higher the level of trust between individuals in a company, the company's development process also accelerates.

According to Starnes, Truhon and McCarthy (2010) in Enaleen Draai (2017), Trust in an organization can be described in three ways, namely: believing in the integrity, character and ability of leaders, believing in the reciprocal relationship of the behavior performed, believing in integrity, honesty or fairness that exists with fellow individuals in a company. According to Rousseau et al in Muhl and Genetics (2017) Trust in an organization is psychological 
consisting of a state of resignation to accept shortcomings based on positive expectations of the intentions or behavior of others. Organizational trust is the expectation of individuals, groups, or organizations, in which they are in a reciprocal interaction that they will make ethical decisions and will develop behavior based on ethical principles (Yucel, 2006 in Akbar, 2020)

\section{Affective Commitment}

Affective commitment related to the emotional aspects, identification and involvement of employees in an organization. Affective commitment is an attitude process in which a person thinks about his relationship with the organization by considering the compatibility between his values and goals with the values and goals of the organization. The degree of conformity between individual values and goals with organizational values and goals shows a direct influence on the individual's desire to stay in the organization. In other words, someone with high affective commitment will be loyal to their organization because they want to stay. This affective commitment will result in the behavior of liking to work as usual, doing the tasks given to him as well as possible and willing to help (Meyer and Allen in Meyer et al., 2002).

Greenberg and Baron (2003) in Hasmarini and Yuniawan (2008) states that affective commitment is the strength of a person's desire to keep working in an organization because they agree with the values and main goals of an organization. Someone feels a high level of affective commitment to remain in an organization because he supports the establishment of an organization and has a desire to help the mission of the organization. Affective commitment according to lease (1998) in Hasmarini and Yuniawan (2008) is a condition in which an employee identifies with the organization and the goals of the organization, and hopes to remain a member of the organization.

Affective commitment is part of organizational commitment which refers to the emotional side of a member regarding his involvement in an organization. There is a tendency that members of an organization with a strong affective commitment will always be loyal to the organization where they work (Robbins, 2008 in Putri and Kusumaputri, 2014). Affective commitment is an emotional feeling for the organization and belief in its values (Robbins and Judge, (2008). According to Meyer and Allen in Rizki and Ibrahim (2018) affective commitment is the emotional attachment that employees have, identify with, and engage employees in organizational activities. Rhoades dkk (2001) in Rizki and Ibrahim, (2018) added that affective commitment is an individual's emotional attachment to the organization which determines individual dedication and loyalty.

Affective commitment can be related to a person's emotional level. According to Novelia et al (2016), affective commitment is a person's emotional involvement in the organization in the form of feelings of love for the organization. According to Alifiulahtin Utaminingsih (2014), is an emotional attachment, identification and involvement in an organization. According to Utaminingsih (2014), affective commitment is a psychological identification which is the pride of being included in the organization. According to Sulianti et al (2014), individuals 
with a strong affective commitment will remain in the organization because they want it. So that affective commitment can be defined as an individual's psychological attachment to remain in the organization.

\section{Research method}

\section{Explanatory Study Research}

This research is an explanatory study, namely research that aims to explain why an event occurs and to build, expand, elaborate or test theory (Neuman, 2011). This study aims to explain the mechanism that underlies the relationship between interpersonal conflict and the behavior of hiding knowledge based on theory. In other words, this research is an explanatory research that uses quantitative methods to test hypotheses empirically. In social research, especially in the field of management, quantitative method is a research method rooted in the positivist social science approach which "emphasizes discovering causal law, careful empirical observations and value-free research" (Neuman, 2014, p. 97). This study then utilizes a crosssectional survey in collecting research data to test the formulated hypotheses.

\section{Results}

\section{Analysis of SEM-PLS}

Data analysis in this study tested the effect of several independent variables on the dependent variable and the moderating variable. Hypothesis testing is done by using the method Partial Least Square (PLS). Partial Least Square is the solution method structural Equation Modelling (SEM). Research with the title of Lonely's influence on Organizational Citizenship Behavior with Commit as moderating on employees of one company PT. Green Planet Indonesia. In analyzing the research data using SEM analysis with the WarpPLS 5.0 application. The steps in analyzing the data are as follows:

1. Outer Model

a. Convergent Validity

Convergent Validity the measurement model can be seen from the correlation between the indicator scores and the construct score (loading factor). According to Chin in Latan and Ghozali (2012), in the early stages of development a loading factor value greater $(>)$ than $0.5-0.6$ can be said to be valid. The loading factor value of each indicator is as follows:

Table 1. The value of Loading Factor Research Variables

\begin{tabular}{|c|c|c|c|c|c|}
\hline Variable & Indicator & $\mathrm{X} 1$ & $\mathrm{X} 2$ & Y1 & Description \\
\hline \multirow[t]{5}{*}{ Procedural Justice } & $\mathrm{X} 1.1$ & $(0.764)$ & & & Valid \\
\hline & $\mathrm{X} 1.2$ & $(0.760)$ & & & Valid \\
\hline & $\mathrm{X} 1.3$ & $(0.853)$ & & & Valid \\
\hline & $\mathrm{X} 1.4$ & $(0.839)$ & & & Valid \\
\hline & $\mathrm{X} 1.5$ & $(0.795)$ & & & Valid \\
\hline
\end{tabular}




\begin{tabular}{|c|c|c|c|c|c|}
\hline & X1.6 & $(0.804)$ & & & Valid \\
\hline \multirow[t]{7}{*}{ Organizational Trust } & X2.1 & & $(0.665)$ & & Valid \\
\hline & $\mathrm{X} 2.2$ & & $(0.766)$ & & Valid \\
\hline & $\mathrm{X} 2.3$ & & $(0.536)$ & & Valid \\
\hline & $\mathrm{X} 2.4$ & & $(0.686)$ & & Valid \\
\hline & X2.5 & & $(0.685)$ & & Valid \\
\hline & $\mathrm{X} 2.6$ & & $(0.830)$ & & Valid \\
\hline & $\mathrm{X} 2.7$ & & $(0.561)$ & & Valid \\
\hline \multirow[t]{6}{*}{ Affective Commitment } & Y1.1 & & & $(0.719)$ & Valid \\
\hline & Y1.2 & & & $(0.699)$ & Valid \\
\hline & Y1.3 & & & $(0.757)$ & Valid \\
\hline & Y1.4 & & & $(0.822)$ & Valid \\
\hline & Y1.5 & & & $(0.769)$ & Valid \\
\hline & Y1.6 & & & $(0.552)$ & Valid \\
\hline
\end{tabular}

Notes: Processed Data, 2021

Based on the data presented in table 1 above, it is known that each indicator of the research variable has a value of outer loading $>0.7$. According to Chin as quoted by Imam Ghozali, the outer loading value between $0.5-0.6$ is considered sufficient to meet the convergent validity requirements. The data above shows that there is no variable indicator whose outer loading value is below 0.5 , so all indicators are declared feasible or valid for research use and can be used for further analysis.

b. Discriminant Validity

In this section, the results of the discriminant validity test will be described. To evaluate the validity of the discriminant, it can be seen with the AVE (Average Variance Extracted) method for each construct or latent variable. The model has better discriminant validity if the square of AVE (Average Variance Extracted) for each construct is greater than the correlation between the two constructs in the model.

Table 2. AVE Squared Value of Research Variables

\begin{tabular}{|l|c|c|}
\hline \multicolumn{1}{|c|}{ Variable } & Average Variance Extracted (AVE) & Description \\
\hline Procedural Justice & 0,65 & Valid \\
\hline Organizational Trust & 0,50 & Valid \\
\hline Affective Commitment & 0,52 & Valid \\
\hline
\end{tabular}

Based on table 2 above, it shows that the AVE (Average Variance Extracted) value for all constructs has a value $>0.50$. Therefore, there is no discriminant validity problem in the model being tested.

Table 3. AVE Root Value and Correlation between Latent Variables

\begin{tabular}{|c|c|c|c|c|}
\hline Variable & KP & KO & KA & Description \\
\hline
\end{tabular}




\begin{tabular}{|c|c|c|c|c|}
\hline KP & $\mathbf{0 . 8 0 4}$ & 0.657 & 0.509 & Valid \\
\hline KO & 0.657 & $\mathbf{0 . 6 8 2}$ & 0.656 & Valid \\
\hline KA & 0.509 & 0.656 & $\mathbf{0 . 7 2 4}$ & Valid \\
\hline
\end{tabular}

Notes: Processed Data, 2021

Based on the data presented in table 3, for each number in bold is the root value of the AVE (Average Variance Extracted) of each construct and the number that is not in bold is the correlation value between constructs and other constructs in the model. So it can be concluded from the results of table 2 and 3 that all constructs meet the criteria of discriminant validity.

c. Composite Reliability

Composite Reliability is the part that is used to test the value of the reliability of the indicators on a variable. A variable can be declared to meet composite reliability if it has a composite reliability value $>0.7$ The following is the composite reliability value of each variable used in this study:

Table 4. Composite Reliability Variable

\begin{tabular}{lcc}
\hline \multicolumn{1}{c}{ Variable } & Composite Reliability & Description \\
\hline Procedural Justice & 0,916 & Reliable \\
Organizational Trust & 0,857 & Reliable \\
Affective Commitment & 0,867 & Reliable \\
\hline Notes: Processed Data, 2021
\end{tabular}

Based on the data presented in table 4 above, it can be seen that the composite reliability value of all research variables is $>0.7$. These results indicate that each variable has met composite reliability so that it can be concluded that all variables have a high level of reliability.

d. Cronbach Alpha

The reliability test with the composite reliability above can be strengthened by using the Cronbach alpha value. A variable can be declared reliable or fulfills cronbach alpha if it has a cronbach alpha value $>0.7$. The following is the cronbach alpha value of each variable:

Table 5. Cronbach Alpha Variable

\begin{tabular}{lcc}
\hline \multicolumn{1}{c}{ Variable } & Cronbach's Alpha & Description \\
\hline Procedural Justice & 0,890 & Reliable \\
Organizational Trust & 0,804 & Reliable \\
Affective Commitment & 0,815 & Reliable \\
\hline
\end{tabular}


Based on the data presented above in table 5, it can be seen that the Cronbach alpha value of each research variable is $>0.7$. Thus these results can indicate that each research variable has met the requirements of the Cronbach alpha value, so it can be concluded that all variables have a high level of reliability.

2. Inner Model

Inner model is an analysis conducted to test the research hypothesis and answer the problems posed. Hypothesis testing is carried out according to the research framework carried out to analyze and test directly and indirectly between exogenous and endogenous variables with a moderation model. The significance level of testing this hypothesis is done by looking at the value of the p-value.

Data management in this study uses PLS (partial least square) where the dependent variable is affective commitment $(\mathrm{Y})$, while the independent variable is procedural justice $(\mathrm{X})$, and the mediating variable is organizational trust $(\mathrm{Z})$. The fit model is used with the aim of testing the overall level of suitability of the research model. Testing the significance of the independent variable on the test dependent variable can be declared significant by fulfilling the requirements if the $\mathrm{P}$ value is less than 0.05 .

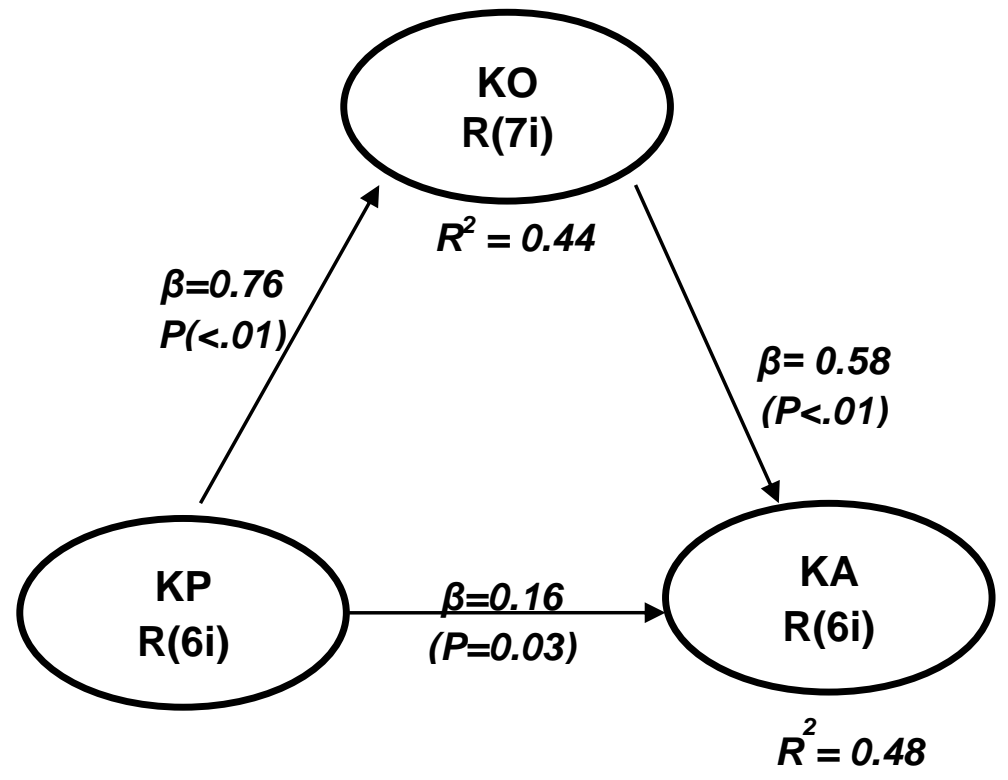

Figure 1. Structural Equations.

Figure 1 showing the path coefficient results with a significance level in accordance with the calculations that have been carried out using Warp PLS, it can be concluded as in table 6 below:

Table 6. Analysis of Path coefficient and $p$ values

\begin{tabular}{cccccc}
\hline \multicolumn{2}{c}{ Relationship between variables } & \multicolumn{2}{c}{ Path Coefficient } & \multicolumn{2}{c}{ Significance Level } \\
\hline Exogenous & Endogenous & Coeff. & $P$-value & value & Description \\
\hline
\end{tabular}




\begin{tabular}{|c|c|c|c|c|c|}
\hline$K P(X)$ & $\mathrm{KA}(\mathrm{Y})$ & 0.155 & 0.030 & $\mathrm{P}<0.001$ & $\begin{array}{l}\text { Significant } \\
\text { Positive }\end{array}$ \\
\hline$K P(\mathrm{X})$ & $K O(Z)$ & 0.666 & $<0.001$ & $\mathrm{P}<0.001$ & $\begin{array}{l}\text { Significant } \\
\text { Positive }\end{array}$ \\
\hline$K O(\mathrm{Z})$ & $K A(Y)$ & 0.581 & $<0.001$ & $\mathrm{P}<0.001$ & Significant \\
\hline$K P(\mathrm{X})-\mathrm{KO}(\mathrm{Z})$ & $K A(Y)$ & 0.387 & $<0.001$ & $\mathrm{P}<0.001$ & Mediate \\
\hline
\end{tabular}

Based on Table 6 shows that:

The first hypothesis examines whether procedural justice has a positive and significant effect on affective commitment. From these results it is stated that procedural justice has a beta coefficient of 0.155 and $\mathrm{p}$ value $<0.030$ on affective commitment. The value of the beta coefficient in a positive direction and with a P-value $<0.05$ (significant) indicates that procedural justice has a positive and significant effect on affective commitment (hypothesis 1 is accepted).

The second hypothesis examines whether procedural justice has a positive and significant effect on organizational trust. From these results, it is stated that procedural justice has a beta coefficient of 0.666 and $p$ value $<0.001$ on organizational trust. The value of the beta coefficient with a positive direction and with a P-value $<$ of 0.05 (significant) indicates that procedural justice has a positive and significant effect on organizational trust (hypothesis 2 is accepted).

The second hypothesis examines whether organizational trust has a positive and significant effect on affective commitment. From these results, it is stated that organizational trust has a beta coefficient of 0.581 and $p$ value $<0.001$ on affective commitment. The value of the beta coefficient in a positive direction and with a P-value $<$ of 0.05 (significant) indicates that organizational trust has a positive and significant effect on affective commitment (hypothesis 3 is accepted).

The fourth hypothesis examines whether procedural justice has a positive and significant effect on affective commitment through organizational trust. From these results it is stated that procedural justice has a beta coefficient of 0.387 and $\mathrm{p}$ value $<0.001$ on affective commitment through organizational trust. The value of the beta coefficient in a positive direction and with a P-value < of 0.05 (significant) indicates that organizational trust has a positive and significant effect on affective commitment (hypothesis 4 is accepted).

\section{Discussions}

\section{Effect of Procedural Justice on Affective Commitment}

The value of the beta coefficient with a positive direction and with a P-value $<$ of 0.05 (significant) indicates that procedural justice has a positive and significant effect on affective commitment. This shows that the better the existing procedural justice, the stronger the affective commitment of ASN will be. In this study, there were still things that needed to be 
improved, namely the indicator "involving all parties concerned" got the lowest score, it was still found that there were employees who were not allowed to provide criticism and suggestions regarding decisions that had been made by the leadership of the organization so that they could impact on the low affective commitment to an organization. Organizational leaders will not be able to make good policies without input from members of the organization itself.

The positive results of this study indicate that employees' perceptions of justice for the procedures used in the organization can affect employees' emotional attachment to the company because they feel involved and get enough information about procedures in making decisions. These results are consistent with research conducted by Ramamoorthy and Flood (2004) in Hasmarini and Yuniawan (2008) which states that procedural justice has a positive and significant effect on affective commitment, the same thing is also found in research Sihana (2016) and Irawan et al. (2016).

\section{Effect of Procedural Justice on Organizational Trust}

The value of the beta coefficient in a positive direction and with a $\mathrm{P}$-value $<$ of 0.05 (significant) indicates that procedural justice has a positive and significant effect on organizational trust. This shows that the better the existing procedural justice, the stronger the organizational trust that arises. In this study, there were still things that needed to be improved, namely the indicator "involving all parties concerned" got the lowest score, it was still found that there were employees who were not allowed to provide criticism and suggestions regarding decisions that had been made by the leadership of the organization so that they could result in low trust in an organization. Organizational trust does not arise without the freedom of members to provide input for the organization itself.

The effect of procedural justice also has an impact on organizational trust where fair procedures can increase employee confidence in an organization. This is reinforced by the findings Dolan (2014) which shows that procedural fairness has a positive and significant impact on organizational trust, Rahmat and Abdillah (2017), Yulianti (2016), Hayunintyas et al., (2018); Yulianti, (2016); Oliver E. Ngodo, (2008)P; Dolan, (2014) and Demir, (2011) also strengthens these findings.

\section{Effect of Organizational Trust on Affective Commitment}

Beta coefficient value is 0,581 and $p$ value $<0,005$ for affective commitment. The value of the beta coefficient in a positive direction and with a P-value $<0.05$ (significant) indicates that organizational trust has a positive and significant effect on affective commitment. Another problem found, namely, on the indicator of "the desire to protect and cover the secrets of others" the researcher found that there are still employees who do not have confidence in the honesty of the leader of an organization where the respondent works so that it can have a low affective commitment to an organization. Low trust in leaders in an organization can have a 
bad impact on the organization itself. Trust in the organization is very important so that members of the organization can contribute to the progress of the organization.

Organizational trust is the will of organizational members to submit themselves to organizational authority in the hope that the organization will realize the positive expectations held by members of the organization. Organizational trust has an influence on affective commitment which is supported by the findings Putri and Kusumaputri (2014), Demir (2011) and Bloemer et al. (2013) with the findings that there is a significant positive relationship between trust and affective commitment to organizational management

\section{Effect of Procedural Justice on Affective Commitment through Organizational Trust}

The value of the beta coefficient in a positive direction and with a P-value $<0.05$ (significant) indicates that organizational trust has a positive and significant effect on affective commitment through organizational trust. In this study, organizational trust strengthens the effect of procedural justice on affective commitment. However, there are still problems that are found, namely, on the indicator "the desire to protect and cover other people's rights" the researcher finds that there are still employees who do not have confidence in the honesty of the leader of an organization where the respondent works so that it can have an impact on weakening the effect of procedural justice on affective commitment in an organization. organization. Low trust in leaders in an organization can have a bad impact on the organization itself. Trust in the organization is very important so that members of the organization can contribute to the progress of the organization (Rahmat et al., 2020).

In the affective commitment variable found the indicator "trying to exceed the standards set by the organization in doing work outside the organization's duties" the researchers found that there were still employees who did not have loyalty to the problems of an organization by not considering problems in the organization as a problem that must be solved by the employee. alone. Low loyalty to this organization can have a bad impact on the organization itself. So that employee trust in an organization must be further improved to strengthen affective commitment. The role of organizational trust as a mediation between the relationship between procedural justice and affective commitment was found in the research Ahmad et al., (2020) with the findings revealing that the mediating role of organizational trust. The role of organizational trust as a mediating variable is also found in research Yulianti, (2016) where organizational trust mediates the relationship between procedural justice and employee engagement.

\section{Conclusion}

From the results that have been described previously, it can be concluded that procedural justice affects the affective commitment of ASN to the Indragiri Hilir Regency Government. Procedural justice affects the trust of ASN organizations in the Indragiri Hilir Regency Government. Organizational trust affects the affective commitment of ASN to the Indragiri 
Hilir Regency Government. Procedural justice affects the affective commitment of ASN to the Indragiri Hilir District Government through organizational trust.

\section{Acknowledgement}

We thank the anonymous reviewers for their valuable support and guidance in improving the quality of the paper. Furthermore, we thank Adi Rahmat and Muhammad Rasyid Abdillah for his feedback on earlier versions of the paper. Besides, we also thank Universitas Lancang Kuning, Indonesia, for their assistance and support along the undertaken of this research.

\section{Disclosure statement}

No potential conflict of interest was reported by the authors.

\section{References}

Ahmad, R., Ahmad, S., Islam, T., \& Kaleem, A. (2020). The nexus of corporate social responsibility (CSR), affective commitment and organisational citizenship behaviour in academia: A model of trust. Employee Relations, 42(1), 232-247. https://doi.org/10.1108/ER-04-2018-0105

Akbar, I. N. (2020). Organizational Trust Dan Organizational Culture Terhadap Employee Engagement Melalui Satisfaction. Jurnal Ilmu Manajemen, 5(2), 206-218.

Al-Zu'bi, H. A. (2010). A Study of Relationship between Organizational Justice and Job Satisfaction. International Journal of Business and Management, 5(12), 102-109. https://doi.org/10.5539/ijbm.v5n12p102

Alifiulahtin Utaminingsih. (2014). Perilaku Organisasi: Kajian Teoritik \& Empirik terhadap Budaya Organisasi, Gaya Kepemimpinan, Kepercayaan dan Komitmen. UB press.

Baharuddin. (2010). Psikologi pendidikan (Ar-Ruzz Me).

Bloemer, J., Pluymaekers, M., \& Odekerken, A. (2013). Trust and affective commitment as energizing forces for export performance. International Business Review, 22(2), 363-380. https://doi.org/10.1016/j.ibusrev.2012.05.002

Demir, M. (2011). Effects of organizational justice, trust and commitment on employees' deviant behavior. Anatolia, 22(2), 204-221. https://doi.org/10.1080/13032917.2011.597934

Dolan, S. L. (2014). Testing the causal relationships between procedural justice, trust and organizational citizenship behavior Testing the causal relationships between procedural justice, trust and organizational citizenship behavior By University of Haifa. May.

Enaleen Draai. (2017). Creating organisational trust. A perspective of the South African public service. Trust in Governance Project Funded by the NRF Post-PhD Track, 87(1,2), 149-200.

Hasmarini, D. P., \& Yuniawan, A. (2008). Pengaruh Keadilan Prosedural Dan Distributif Terhadap Kepuasan Kerja Dan Komitmen Afektif. Pengaruh Keadilan Prosedural Dan Distributif Terhadap Kepuasan Kerja Dan Komitmen Afektif, 17(1), 99-118. https://doi.org/10.14710/jbs.17.1.99-118

Hayunintyas, R. F., Do, B. R., Sudiro, A., \& Irawanto, D. W. (2018). Organizational Justice and Effective Organizational Commitment mediated by Organizational Trust and Perceived Organizational Support: Study at the largest Poultry Industry Company in Indonesia. Asia Pacific Management and Business Application, 6(3), 175-196. https://doi.org/10.21776/ub.apmba.2018.006.03.4

Hwei, S., \& Santosa, T. E. C. (2012). Pengaruh keadilan prosedural dan keadilan distributif terhadap komitmen organisasi. Jurnal Dinamika Ekonomi Dan Bisnis, 9, 37-52.

Irawan, L., Sudarma, K., Manajemen, J., Ekonomi, F., Semarang, U. N., \& Artikel, I. (2016). Pengaruh Keadilan Distributif dan Keadilan Prosedural pada Komitmen Afektif melalui Kepuasan Kerja. Management Analysis Journal, 5(2), 149-155. https://doi.org/10.15294/maj.v5i2.8374

James L. Gibson, et. a. (2012). Organization:Bbehaviour, Structure, Processes.14th Edition (14 th). McGraw-Hill 
Companies, Inc.

Meyer, J. P., Stanley, D. J., Herscovitch, L., \& Topolnytsky, L. (2002). Affective, continuance, and normative commitment to the organization: A meta-analysis of antecedents, correlates, and consequences. Journal of Vocational Behavior, 61(1), 20-52. https://doi.org/10.1006/jvbe.2001.1842

Mighfar, S. (2015). Social exchange theory: Telaah Konsep George C. Homans Tentang Teori Pertukaran Sosial. LISAN AL-HAL: Jurnal Pengembangan Pemikiran Dan Kebudayaan, 9(2), $259-282$. https://doi.org/10.35316/lisanalhal.v9i2.98

Muhl, J. K., \& Genetics, M. (2017). Organizational Trust Measurement, Impact, and the Role of (Issue January 2014). https://doi.org/10.1007/978-3-319-04069-1

Oliver E. Ngodo. (2008). Procedural Justice and Trust: The Link in the Transformational Leadership Organizational Outcomes Relationship Relationship. International Journal of Leadership Studies, 4(1), 82100.

Putri, M., \& Kusumaputri, E. (2014). Kepercayaan (Trust) Terhadap Pengurus Organisasi Dan Komitmen Afektif Pada Organisasi Mahasiswa Daerah Di YOGYAKARTA. Jurnal Psikologi Integratif, 2(1), 53-61.

Rahmat, A., \& Abdillah, M. R. (2017). Pengaruh keadilan organisasi terhadap kepercayaan organisasi ( studi empiris pada seluruh sekolah tinggi ilmu ekonomi di kota pekanbaru. 14(2), 121-130.

Rahmat, A., Abdillah, M. R., Priadana, M. S., Wu, W., \& Usman, B. (2020). Organizational Climate and Performance: The Mediation Roles of Cohesiveness and Organizational Commitment. IOP Conference Series: Earth and Environmental Science, 469(1). https://doi.org/10.1088/1755-1315/469/1/012048

Rahmat, A., Lancang, U., Pekanbaru, K., Hadiyati, H., Lancang, U., Pekanbaru, K., \& Abdillah, M. R. (2017). Pengaruh Keadilan Organisasi Terhadap Kepercayaan Organisasi (Studi Empiris Pada Seluruh Sekolah Tinggi Ilmu Ekonomi Di Kota Pekanbaru. Jurnal Ilmiah Ekonomi Dan Bisnis, 14(2), 11.

Rizki, R., \& Ibrahim, M. (2018). Pengaruh karakteristik pekerjaan terhadap motivasi intrinsik untuk berbagi pengetahuan secara online dengan menggunakan affective commitment sebagai mediasi pada karyawan pt. Pertamina (persero) aceh. Jurnal Ilmiah Mahasiswa Ekonomi Manajemen, 3(1), 105-116.

Robbins, P. S. dan T. A. J. (2012). Perilaku Organisasi.

Sihana, T. (2016). Pengaruh Keadilan Distributif dan Keadilan Prosedural pada Komitmen Afektif melalui Kepuasan Kerja. Management Analysis Journal, 5(2). https://doi.org/10.15294/maj.v5i2.8374

Widiastuti, R. K., \& Aisyah, M. N. (2016). Pengaruh Keadilan Prosedural Terhadap Kinerja Karyawan Dengan Tingkat Kepuasan Karyawan Sebagai Variabel Intervening. Nominal, Barometer Riset Akuntansi Dan Manajemen, 5(1), 88-96. https://doi.org/10.21831/nominal.v5i1.11478

Yulianti, P. (2016). Procedural Justice, Organizational Trust, Organizational Identification dan Pengaruhnya pada Employee Engagement. Jurnal Manajemen Teori Dan Terapan/ Journal of Theory and Applied Management, 9(3), 210-225. https://doi.org/10.20473/jmtt.v9i3.3076 